\title{
Selected Health Attitudes (Physical Activity and Nutrition) of 18-Year-Old Girls Graduating from Secondary Schools of Tricity ${ }^{*}$
}

DOI: $10.2478 / v 10131-011-0011-7$

Authors' Contribution: A - Study Design B - Data Collection C - Statistical Analysis D - Data Interpretation E - Manuscript Preparation F - Literature Search $\mathrm{G}$ - Funds Collection

\author{
Anna Walentukiewicz ${ }^{1}$ (A, B, C, D, E, F, G) , Anna Łysak ${ }^{2}$ (A, B, D, E), \\ Barbara Wilk' (D, E, F, G) \\ ${ }^{1}$ Jedrzej Sniadecki Academy of Physical Education and Sport in Gdansk, \\ Dep. of Health Promotion, Poland \\ 2 Jedrzej Sniadecki Academy of Physical Education and Sport in Gdansk, \\ Dep. of Physiotherapy, Poland
}

Key words: health attitudes, eating habits, physical activity

Abstract
Background:

Material/Methods: In the school year 2010/2011 research among randomly chosen pupils of secondary schools in Gdańsk was conducted. Basic anthropometric measurements of the studied $3^{\text {rd }}$ grade schoolgirls (body height, body mass, evaluation of body composition) were carried out. A questionnaire consisting of 3 parts concerning health attitudes was the basic research tool.

Results: Irregularities in nutritional behaviours in the studied schoolgirls were revealed, and in particular resignation from eating the first breakfast, insufficient consumption of vegetables and fruit. It was noticed that the level of physical activity investigated by IPAQ questionnaire is at a low level. The majority of girls showed a low or average level of health attitudes (HA).

Conclusions: Learning about health attitudes will allow schools to diagnose these behaviours and to prepare proper programmes promoting health.

\begin{tabular}{l|l|l} 
Abbrevations used: & $\mathrm{PA}-$ physical activity & $\% \mathrm{FM}$ - percentage of fat mass in \% \\
$\mathrm{HA}-$ health attitudes & X - mean value \\
& $\mathrm{HAI}-$ health attitude index & $\mathrm{SD}-$ standard deviation \\
& $\mathrm{IPAQ}-$ International Physical Activity & Me - median \\
& Questionnaire & IQR - Interquartile Range \\
& $\mathrm{BMI}-$ body mass index & MET - Metabolic Equivalent of Work
\end{tabular}

Word count: 3004

Tables: 3

Figures: 2

Received: April 2011

References: 41

Accepted: June 2011

Published: June 2011

Address for correspondence:

Dr Anna Walentukiewicz,

Academy of Physical Education and Sport Dep. of Health Promotion, 80-336 Gdańsk, Poland, ul. K. Górskiego 1

Phone +4858/5547157, e-mail: annawalentukiewicz@wp.pl

\footnotetext{
* Work done as part of own research
} 


\section{Introduction}

Along with development of civilisation the importance of physical activity and other health attitudes disappears. It is emphasised in literature that the level of activity, the way of nutrition and other determinants of lifestyle influence to an essential degree human physical, intellectual and mental development including well-being [1,2]. Increasing activity and rational nutrition is one of the main goals of modern strategy of public health. Beside the value of body mass index (BMI), among components of the assessment of health condition, eating behaviours and level of physical activity are vital. Attention is also drawn to the fact that women play a particular role in health education in a family, first of all due to participation in forming needs and eating habits, participation of children in physical culture and active rest as well as prophylactic care. Moreover, school has the biggest possibilities of pedagogising (including future mothers) within promotion of health attitudes $[2,4,5,6]$.

The objective of the conducted research was to study health attitudes of girls graduating from secondary schools, and its main purpose was to assess the dependencies between the degree of intensity of health attitudes, eating behaviours, the level of physical activity and the value of the body mass index (BMI).

\section{Material and methods}

In the school year 2010/2011 research was conducted among randomly chosen youth from secondary schools in Gdańsk. Altogether 586 pupils participated in the research, from which 393 girls were selected from the $3^{\text {rd }}$ grade. Each time the school principal gave permission for the study. The research was conducted at physical education lessons. Basic anthropometric measurements of the schoolgirls were taken. Portable Height Meter SECA 217 was used to measure the body height, and the body mass and the measurements of components were assessed by means of Tanita $410 \mathrm{BC}$ analyser of body composition. Characteristics of the subjects was supplemented by determining excess and deficiency in body mass, which were estimated by means of international criterion IOTF $[7,8]$. The basic research tool was the questionnaire concerning health attitudes. In this research results concerning health attitudes and physical activity are presented. To establish the level of presented physical activity (PA), the International Questionnaire of Physical Activity (IPAQ) was used. It serves measuring physical activity within the last 7 days and may be applied in persons aged 15-69 [9,10,11]. A short questionnaire used in the research includes 7 questions concerning all kinds of physical activity connected with daily life, work and rest. Activities lasting at least 10 min (without break) conducted during work at home, in its surroundings and in transferring from place to place and in free time spent on recreation, exercise and sport were taken into consideration. Information was collected on the time spent on sitting, walking and the time spent on physical activity - intensive and moderate. Consumption of chosen sources of fibre and fats was determined by means of frequency of food consumption. Block's questionnaire was used to assess the consumption of fruit, vegetables and fibre as well as fat in Roszkowski's interpretation [12,13]. Information about the habitual frequency of consumption during the last year of the mentioned in the questionnaire food groups was collected in an interview. Frequency was determined in a 5-point scale, to which points 0 to 4 were ascribed. Fibre consumption was presented in the point scale (0-36 points) and fat (0-52 points), and on this basis respondents were classified to particular groups (Tab. 3). Assessment of health attitudes (HA) was conducted using the Inventory of Health Attitudes [14], which is a tool of self-description including 24 statements concerning various types of behaviours associated with health. The responses could be divided into 5 categories: almost never, rarely, from time to time, often and almost always to which points from 1-5 were ascribed. The achieved points were summed up. The general indicator of the intensity of health attitudes measured by scale HAI is within limits 24-120 points. The higher the result, the higher the intensity of declared health attitudes. The received number of points was calculated according to gender into a sten scale, which was interpreted in category of low results (1-4 sten), average (5-6 sten) and high (7-10 sten). Statistical analysis was conducted basing on computer software STATISTICA v.8.0 (StatSoft Poland). The values of analysed measurable parameters were presented in form of average values and standard deviations, and of the 
immeasurable ones by means of cardinality and percentage. In order to study the dependencies between groups for quantitative variables with regard to the lack of normality of distribution (verified by the Shapiro-Wilk test) and for ordinal variables nonparametric statistics were applied - the Kruskala-Wallis test assuming the level of significance at $p<0.05$.

\section{Results}

Anthropometric characteristics of the researched group are presented in Table 1. On the basis of the conducted anthropometric mass and body height measurements, the value of the body mass index was calculated (BMI). It was noted, on the basis of the IOTF criterion, that $14 \%$ of the studied girls were characterised by deficiency in body mass and $16 \%$ by its excess (Table 3 ).

Tab. 1. Anthropometric characteristics of the studied girls

\begin{tabular}{|l|c|c|c|c|}
\hline & $\mathrm{x}$ & $\mathrm{SD}$ & Min & Max \\
\hline Age (years) & 18.7 & 0.45 & 18 & 19 \\
\hline Height $(\mathrm{m})$ & 1.66 & 0.06 & 1.49 & 1.84 \\
\hline Mass $(\mathrm{kg})$ & 60.55 & 10.99 & 40.4 & 116.5 \\
\hline BMI $\left(\mathrm{kg} / \mathrm{m}^{2}\right)$ & 21.75 & 4.39 & 14.66 & 49.16 \\
\hline FAT \% & 24.11 & 7.45 & 2.4 & 49.7 \\
\hline Waist circumference & 70.69 & 8.74 & 55.0 & 121.0 \\
\hline Hips circumference & 96.45 & 7.68 & 69.0 & 143.0 \\
\hline WHR & 0.73 & 0.06 & 0.61 & 1.01 \\
\hline X- arithmetic mean & SD - standard deviation
\end{tabular}

A high level of physical activity was presented by $6 \%$ of subjects (Fig. 1). This category comprises persons who meet one of the following criteria: 3 or more days of intensive physical effort (altogether at least 1500 MET min/week) or 7 or more days of any combination of efforts (walking, moderate or intensive efforts) exceeding $3000 \mathrm{MET} /$ week [9,10]. Physical activity allowing to qualify them to the level of sufficient PA was achieved by $32 \%$ of all subjects (Fig. 1). This level was achieved by persons who met of the criteria: 3 or more days of intensive physical effort, not less than 20 min a day; 5 or more days of moderate effort or walking not less than 30 min a day; 5 or more days of any combination of effort (walking, moderate or intensive efforts exceeding $600 \mathrm{MET}$-min/week. The respondents who did not participate in any physical activity, or did not meet conditions for achieving a high or sufficient level and hence were classified at an insufficient level amounted to $62 \%$ of all subjects.

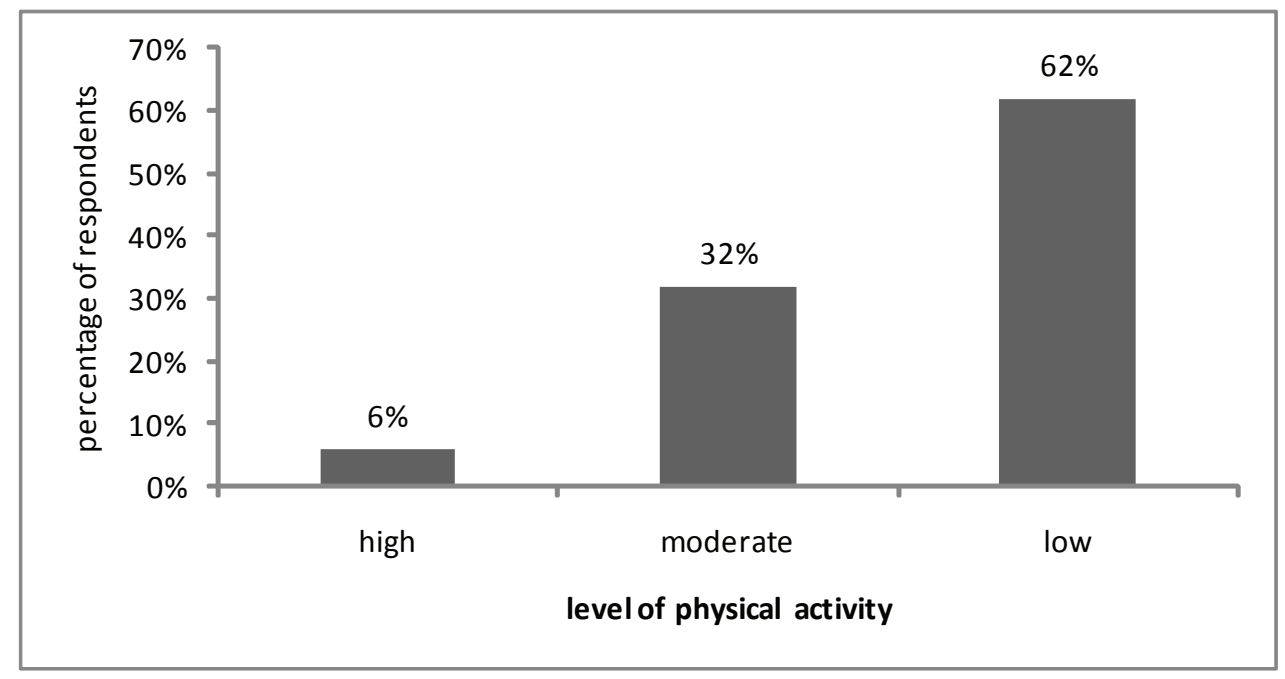

Fig 1. The level of physical activity in the studied schoolgirls 
Basic statistical characteristics of assessment of habitual eating behaviours in the researched group of schoolgirls is presented in Table 3. Analysis showed that the subjects ate from 2 to 5 meals a day. Persons eating 4 basic meals dominate in the group of respondents. Altogether $62 \%$ of the participants of the research consumed the recommended number of meals during a day. The subjects were asked about the frequency of eating the first breakfast $-49 \%$ from them declared always eating this meal. Almost every $10^{\text {th }}$ schoolgirl declared avoiding this meal permanently. The most important meal in the subjects' opinion was dinner. Consumption of the chosen sources of fibre at a deficiency level was revealed by $88 \%$ of the subjects. $16 \%$ schoolgirls had a fat rich diet. The majority of subjects (40\%) assessed their way of eating as proper.

The results of the study indicate that the general index of intensity of health behaviour for the researched group was $75.94(S D=12.87)$, which corresponds per standardized unit to the level of 4 stens and is interpreted as a low result. When analyzing particular categories of health attitudes, it was noted that proper eating habits were the highest and the weakest assessed health practices (Tab. 2) Along with the growth in health attitudes intensity, an increase in PA, an increase in fibre consumption and a decrease in fats consumption was noticed (Fig. 2); however, the intensity of these tendencies was too weak. Table 3 presents dependencies of selected components of lifestyle of the studied girls - eating behaviours and the PA level - on the degree of intensity of health attitudes measured by questionnaire HAl. Analyzing variables of nutritional behaviours (eating first breakfast, consuming fats, importance of meals) with regard to the declared health attitudes, vital statistical differences were noticed in the researched group (Tab. 3).

Tab. 2. Average results of the assessment of the HAl scale among the studied schoolgirls

\begin{tabular}{|l|c|c|}
\hline HAl categories & X & SD \\
\hline General indicator of behaviours & 75.94 & 12.87 \\
\hline Proper nutritional habits & 3.26 & 0.77 \\
\hline Prophylactic behaviours & 3.12 & 0.87 \\
\hline Positive psychological attitude & 3.24 & 0.76 \\
\hline Health practices & 3.08 & 0.67 \\
\hline
\end{tabular}

$\mathrm{x}$ - arithmetic mean SD - standard deviation

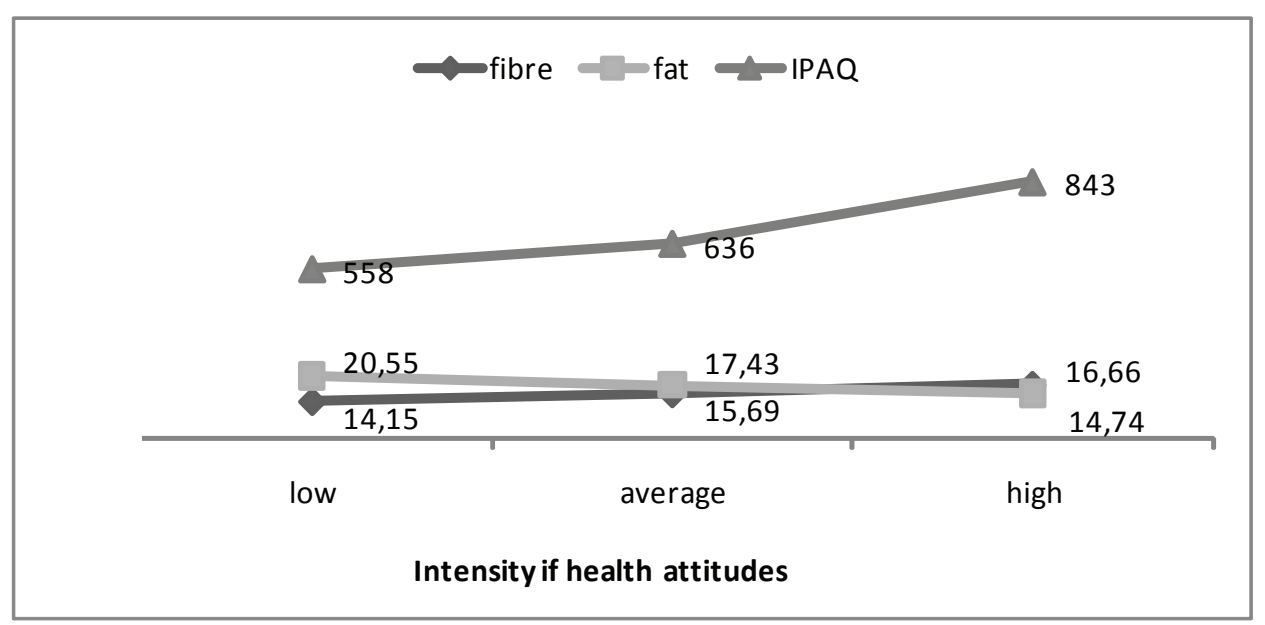

Fig 2. Fat and fibre consumption and physical activity in categories of intensity of health attitudes by 18 -yearold girls graduating from secondary schools in Tricity 
Tab. 3. Deficiency and excess of body mass, health attitudes and the level of physical activity depending on the degree of intensity of health attitudes ( $\mathrm{HAl}$ ) of 18-year-old girls graduating from secondary schools

\begin{tabular}{|c|c|c|c|c|c|c|c|c|}
\hline \multirow{3}{*}{ Name of variable } & \multirow{2}{*}{\multicolumn{2}{|c|}{ altogether }} & \multicolumn{6}{|c|}{ HAl index } \\
\hline & & & \multicolumn{2}{|c|}{ low } & \multicolumn{2}{|c|}{ average } & \multicolumn{2}{|c|}{ high } \\
\hline & $\mathrm{N}=393$ & $\%$ & $\mathrm{~N}=210$ & $\%$ & $\mathrm{~N}=144$ & $\%$ & $\mathrm{~N}=39$ & $\%$ \\
\hline \multicolumn{9}{|l|}{ BMI $p=0,6027$} \\
\hline Deficiency of body mass & 57 & 14.50 & 33 & 15.71 & 17 & 11.81 & 7 & 17.95 \\
\hline Norm & 273 & 69.47 & 142 & 67.62 & 102 & 70.83 & 29 & 74.36 \\
\hline Excess of body mass & 63 & 16.03 & 35 & 16.67 & 25 & 17.36 & 3 & 7.69 \\
\hline \multicolumn{9}{|l|}{ Obesity } \\
\hline \multicolumn{9}{|l|}{ Number of meals $p=0.8835$} \\
\hline Two & 32 & 8.14 & 20 & 9.52 & 11 & 7.64 & 1 & 2.56 \\
\hline Three & 120 & 30.53 & 65 & 30.95 & 41 & 28.47 & 14 & 35.90 \\
\hline Four & 152 & 38.68 & 73 & 34.76 & 65 & 45.14 & 14 & 35.90 \\
\hline Five & 89 & 22.65 & 52 & 24.76 & 27 & 18.75 & 10 & 25.64 \\
\hline \multicolumn{9}{|l|}{ First breakfast $p=0.0007$} \\
\hline Always & 193 & 49.11 & 95 & 45.24 & 75 & 52.08 & 14 & 35.90 \\
\hline Frequently & 86 & 21.88 & 36 & 17.14 & 40 & 27.78 & 14 & 35.90 \\
\hline Rarely & 77 & 19.59 & 50 & 23.81 & 21 & 14.58 & - & - \\
\hline Never & 37 & 9.41 & 29 & 13.81 & 8 & 5.56 & 1 & 2.56 \\
\hline \multicolumn{9}{|c|}{ The most important meal $p=0.0104$} \\
\hline First breakfast & 179 & 45.55 & 81 & 38.57 & 72 & 50.00 & 26 & 66.67 \\
\hline Dinner & 196 & 49.87 & 114 & 54.29 & 69 & 47.92 & 13 & 33.33 \\
\hline Supper & 18 & 4.58 & 15 & 7.14 & 3 & 2.08 & - & \\
\hline \multicolumn{9}{|c|}{ Self-assessment of nourishment $p=0.0595$} \\
\hline Proper & 154 & 39.19 & 48 & 22.86 & 74 & 51.39 & 33 & 84.62 \\
\hline I don't know & 120 & 30.53 & 72 & 34.29 & 43 & 29.86 & 4 & 10.26 \\
\hline Improper & 119 & 30.28 & 90 & 42.86 & 27 & 18.75 & 2 & 5.13 \\
\hline \multicolumn{9}{|c|}{ Fibre consumption $p=0.6903$} \\
\hline Sufficient (>30 pts) & 1 & 0.25 & - & - & 1 & 0.69 & - & - \\
\hline Insufficient (20-29 pts) & 45 & 11.45 & 23 & 10.95 & 15 & 10.42 & 6 & 15.38 \\
\hline Poor $(<20$ pts $)$ & 347 & 88.30 & 187 & 89.05 & 128 & 88.89 & 33 & 84.62 \\
\hline \multicolumn{9}{|l|}{ Fat consumption $p=0.0001$} \\
\hline Recommended (<18 pts) & 207 & 52.67 & 88 & 41.90 & 90 & 62.50 & 29 & 74.36 \\
\hline Satisfactory (18-21 pts) & 65 & 16.54 & 40 & 19.05 & 16 & 11.11 & 2 & 5.13 \\
\hline Moderate (22-24 pts) & 59 & 15.01 & 38 & 18.10 & 21 & 14.58 & 6 & 15.38 \\
\hline Unsatisfactory (25-27 pts) & 27 & 6.87 & 30 & 14.29 & 5 & 3.47 & 1 & 2.56 \\
\hline Unacceptable (> $27 \mathrm{pts})$ & 35 & 8.91 & 14 & 6.67 & 12 & 8.33 & 1 & 2.56 \\
\hline \multicolumn{9}{|l|}{ PA level $p=0.4863$} \\
\hline Insufficient & 243 & 61.83 & 132 & 62.86 & 90 & 60.5 & 21 & 53.85 \\
\hline Sufficient & 125 & 31.81 & 67 & 31.90 & 44 & 30.56 & 14 & 35.90 \\
\hline High & 25 & 6.36 & 11 & 5.24 & 10 & 6.94 & 4 & 10.26 \\
\hline \multicolumn{9}{|c|}{ Limiting salt consumption favours health $p=0.0346$} \\
\hline Yes & 377 & 95.93 & 191 & 91.00 & 138 & 95.83 & 39 & 100 \\
\hline No & 16 & 4.07 & 19 & 9.00 & 6 & 4.17 & - & - \\
\hline \multicolumn{9}{|c|}{ PA is one of the methods of civilisation diseases prevention } \\
\hline Yes & 357 & 90.84 & 183 & 87.00 & 138 & 95.83 & 38 & 97.44 \\
\hline No & 36 & 9.16 & 27 & 13.00 & 6 & 4.17 & 1 & 2.56 \\
\hline
\end{tabular}

Kruskal-Wallis test level of significance $p<0.05$

\section{Discussion}

Human health can be understood in many ways, from the state of non reflective reality, "the highest good, optimal functioning of organism, so called silence of organs to the process of autocreation in integration with environment" [15]. In search of non-pathological health conditions the first place is taken by readiness to act for its benefit and health attitudes. As an integral component of a complex process of adaptation during human evolution, physical activity is a vital component 
of supporting health as well as its positive measure $[16,17]$. Both its excess and deficiency may be a reason for many disturbances and aggravated risk of incidence of certain diseases. According to the majority of recommendations its daily dose for children and youth (to 18 years of age) should be 60 minutes [18]. However, for adults these recommendations vary. According to ASCM, to support the value of health, the recommended PA level is 150 minutes of moderate effort in a week. US Dietary Guidelines and American College of Sports Medicine and the American Health Association recommends 30 min of daily physical activity to maintain health. In order to lower the risk associated with so-called incidence of chronic non-infectious civilisation diseases Physical Activity Guidelines Advisory Committee Report recommends 2.5 hours of moderate to intensive physical activity in a week in order to lower the risk of breast and large intestine cancer and to control the body mass, but the length of training should be extended to 3.5 hour in a week [18]. According to the decisions of the First Mike Stock Conference, 30 minutes of additional physical effort performed in free time should be sufficient to prevent heart diseases and diabetes type II, 45-60 minutes to prevent excess of body mass, 60-90 minutes to prevent secondary growth of body mass in the obese $[19,20]$. The benefits coming from regular physical activity are unquestionable, beginning from the obvious ones, such as limiting the risk of cardiovascular disorders, delay and/or stopping the development of arterial hypertension, preserving metabolic functions, decreasing diabetes type 2 incidence, decreasing the risk of obesity, increasing mineralisation of bones, maintaining motor functions (to mention just a few of them) to maintaining cognitive functions, and the economic and social aspects. Naturally, the reasons for taking up physical activity are various. Among girls, the most frequently mentioned reason for which physical activity is taken up is body mass control, then improvement in attractiveness and physical fitness, while among boys it is the improvement in musculature, fitness and attractiveness. What should also be emphasized, hypokinesis is an independent factor of the development of chronic diseases and premature death [21]. Promotion of physical activity constitutes one of the main determinants of health of the population, and as a component of health promotion it is the only one from among vital conditions determining the health of the population [22]. The results show that the percentage of youth at a satisfactory PA level is getting lower [23,24,25]. By assessing the number of days and an average duration of physical activity in a week among the subjects, it should be stated that the schoolgirls did not achieve the PA level recommended in the prophylaxis of civilisation diseases, and prophylaxis of diet-dependent diseases may be effective only when the correct nutrition will be accompanied by a proper level of physical activity. A positive phenomenon observed in the research is the fact that along with the rise of the intensity of health attitudes, an increase in PA value expressed by IPAQ value was noted; the same dependency was observed with an increase in body fat. In the researched group the excessive body mass (BMI $\leq 25 \mathrm{~kg} / \mathrm{m}^{2}$ ) was noticed in $16 \%$ of girls. The girls who were characterised by extreme body fat had the fullest knowledge on the influence of nutrition and physical activity on origins of diseases. Any observed "positive directions" should be considered as favourable, but the intensity of these changes was too low. Having knowledge about lifestyle beneficial for health is insufficient to maintain proper body mass. This knowledge is broadened with age, but as it follows from extensive research, it is not always applied in practice $[1,26,27,28]$. Results of many studies confirm the relations between health attitudes and condition of health of an individual. The assessment of the intensity of health attitudes of the subjects allow stating that the girls graduating from secondary schools, most often presented low $(53 \%)$ and average health attitudes (37\%). Kozieł at al. [29], Naszydłowska at al. [30] and Lewko at al. [31] achieve coincident results. Rational nutrition means not only a proper diet, balanced with respect to energy and nutritional components, but also a proper (adapted to age) number of consumed meals and their distribution during the day. Girls nutritional behaviours are not properly shaped. The research shows the number of consumed meals, avoiding the consumption of breakfast, rare consumption of fruit and vegetables, which strays from pro-health recommendations [32,33], but also from the respondents' knowledge. A habitual number of consumed meals should be $4-5.38 \%$ of girls in the researched group did not meet this standard. Personal research confirmed observations of other authors in this area $[33,34,35,36]$. Avoiding the consumption of the first breakfast is also a big problem. Research $[37,38]$ confirmed the relation 
between not eating breakfast and the occurrence of obesity. This meal is essential for effective functioning of a pupil at school. According to own research, breakfast is never eaten by $9 \%$ of girls. Suliga [39] indicated a smaller (5.8\%) percentage of youth never eating breakfast, while Hamułka at al. [40] (14.8\%) and Piotrowska at al. [41] (15.2\%) bigger. Nutrition undergoes automation and lack of consciousness committed in this respect mistakes (despite the presented high nutritional knowledge) in the long run may unfavourably influence the schoolgirls' health. The most important recommendations concerning the promotion of daily PA and healthy eating were not met. The researched 18-year-olds showed slight interest in making so-called "good choices", which is important from the point of view of indications to stimulate and modify positive health attitudes and to modify attitudes which are risky for health.

Learning health attitudes of schoolchildren graduating from secondary school will allow the school to notice the need for health education in the process of education and will enable drawing up prophylactic programmes shaping positive attitudes of these pupils towards their own health (schools participating in the research got the results of this study from the authors).

\section{Conclusions}

1. The research indicated that favourable health attitudes are not common, and the majority of subjects present low and average health attitudes.

2. Analysing reasons for such attitudes as well as creating reparation programmes directed at abnormalities found in lifestyle becomes necessary.

\section{References}

1. Misiuna M, Szcześniewska D. Zachowania zdrowotne mieszkańców Warszawy [in Polish] [Health behaviors of inhabitants of Warsaw]. Zdr Publ 2003;113(1/2):28-36.

2. Kłos J, Gromadecka-Sutkiewicz M. Styl życia młodzieży w ujęciu strukturalnym [Youth’s lifestyle in a structural view]. Probl Hig Epidemiol 2011;92(1):120-126.

3. Mazur J. Społeczne uwarunkowania zdrowia subiektywnego młodzieży szkolnej w wieku 11-15 lat w Polsce na tle danych europejskich [in Polish] [Social determinants of subjective health among school youth aged 11-15 compared to European data]. Med Wieku Rozw 2010;14(2):169-178.

4. Woynarowska B. Edukacja zdrowotna [Health Education]. Warszawa: PWN; 2008.

5. Maszczak T. Wychowanie fizyczne w nowym systemie edukacji - szanse i zagrożenia [in Polish] [Physical Education in the new educational system - opportunities and threats]. Wych Fiz $i$ Zdr 2000;5:196-199.

6. Wrona-Wolny W. Styl życia z perspektywy praktyki nauczyciela [in Polish] [Lifestyle from the perspective of a teacher's practice]. In: Drabik J, Resiak M, editors. Nauczyciel jako pedagog i promotor zdrowia [Teacher as a pedagogue and a health promoter]. Gdańsk: Wydawnictwo AWFiS; 2009, 119-172.

7. Cole TJ, Bellizzi MC, Flegal KM, Dietz WH. Establishing a standard definition for child overweight and obesity worldwide: international survey. BMJ 2000;320:1240-3.

8. Cole TJ, Flegal KM, Nicholls D, Jackson AA. Body mass index cut offs to define thinness in children and adolescents: international survey. BMJ 2007;335:166-167.

9. Biernat E, Stupnicki R, Gajewski AK. Międzynarodowy Kwestionariusz Aktywności Fizycznej (IPAQ) wersja polska [in Polish] [International Physical Activity Questionnnaire - the Polish Version]. Wych Fiz i Zdr 2007;6/7:4-10.

10. Biernat E, Stupnicki R. Przegląd międzynarodowych kwestionariuszy stosowanych w badaniu aktywności fizycznej [in Polish] [An overview of International Questionnaires used in studying physical activity]. Wych Fiz i Sport 2005;2:61-73.

11. Guidelines for data processing and analysis of the International Physical Activity Questionnaire. www.ipaq.ki.se/scoring.html. [accessed 2010.06.10]

12. Thompson FE, Byers T. Dietary assessment resource manual. J Nutr 1994;124:2245-2317.

13. Roszkowski W. Ocena sposobu żywienia i stanu odżywienia [in Polish] [An assessment of the way of nutrition and the state of nourishment]. In: Roszkowski W, editor. Podstawy nauki o żywieniu człowieka. Przewodnik do ćwiczeń [Basics of the science of human nutrition. Guidebook for classes]. Warszawa: SGGW, 2000, 133-141.

14. Juczyński Z. Narzędzia pomiaru w promocji i psychologii zdrowia [in Polish] [Tools of measurement in the promotion and psychology of health]. Warszawa: PTP; 2009. 
15. Drabik J. Nauczyciel wobec różnych obszarów zdrowia - wprowadzenie [in Polish] [A teacher and various areas of health - an introduction] In: Drabik J, Resiak M, editors. Nauczyciel jako pedagog i promotor zdrowia [A teacher as a pedagogue and a health promoter]. Gdańsk: Wydawnictwo AWFiS; 2009, 174.

16. Drabik J. Promocja aktywności fizycznej (wprowadzenie do problematyki). Część III. [Promotion of Physical Activity (introduction to the subject). Part III]. Gdańsk: Wydawnictwo AWF; 1997.

17. Przewęda R., Dobosz J., Kondycja fizyczna polskiej młodzieży [in Polish] [Physical condition of Polish youth]. Warszawa: Wydawnictwo AWF; 2003.

18. Andersen RE, Jakicic JM. Interpreting the physical activity guidelines for health and weight management. J Phys Act Health 2009;6(5):651-6.

19. Saris WHM, Blair SN, van Baak MA, et al. How much physical activity is enough to prevent unhealthy weight gain? Outcome of the IASO 1st Stock Conference and consensus statement. Obes Rev 2003;4:101-114.

20. Plewa M, Markiewicz A. Aktywność w profilaktyce i leczeniu otyłości [in Polish] [Activity in the Prophylaxis and Treatment of Obesity]. Endokr Otyłość 2006;1:30-37.

21. Raport UE. Wytyczne UE Dotyczące aktywności fizycznej. Zalecane działania polityczne wspierające aktywność fizyczną wpływająca pozytywnie na zdrowie. Czwarty projekt skonsolidowany zatwierdzony przez Grupę Roboczą UE: Sport i Zdrowie" [in Polish] [EU Report. EU Guidelines Regarding Physical Activity. Recommended political actions supporting physical activity favourably influencing health. Fourth consolidated project approved of by the EU Working Group "Sport and Health"]. Brussels; 2008.

22. Drabik J. Zdrowie fizyczne [Physical health]. In: Drabik J, Resiak M, editors. Styl życia w promocji zdrowia [Lifestyle in health promotion]. Gdańsk: Wydawnictwo AWFiS; 2010, 176-192.

23. Oblacińska A, Woynarowska B, editors. Zdrowie subiektywne, zadowolenie z życia i zachowania zdrowotne uczniów szkół ponadgimnazjalnych w Polsce w kontekście czynników psychospołecznych i ekonomicznych [in Polish] [Subjective Health, Satisfaction with life and health behaviours of secondary school pupils in Poland in the context of psychosocial and economic factors]. Warszawa: IMiD; 2006.

24. Woynarowska B. Zdrowie i zachowania zdrowotne uczniów kończących gimnazja i szkoły ponadgimnazjalne w Polsce [in Polish] [Health and health behaviours of pupils graduating from intermediate and secondary schools in Poland]. Zdrowie-Kultura Zdrowotna-Edukacja 2008;1:47-53.

25. Saracen A. Zachowania zdrowotne młodzieży szkół ponadgimnazjalnych [in Polish] [Health behaviours of secondary school youth]. Hygeia Public Health 2010;45(1):70-73.

26. Stankiewicz $M$, Pieszko $M$, Śliwińska $A$, et al. Występowanie nadwagi i otyłości oraz wiedza i zachowania zdrowotne dzieci i młodzieży małych miast i wsi - wyniki badania Polskiego Projektu 400 Miast [in Polish] [Incidence of obesity and the knowledge and health education of children and youth of small towns and villages - results of the research Polish Project 400 Towns]. Endokr Otyłość 2010;6(2):59-66.

27. Chalcarz W, Klemczak L, Krajewski P. Wpływ wiedzy uczniów Zespołu Szkół Gastronomicznych i ich miejsca zamieszkania na sposób żywienia i stan odżywienia [in Polish] [The influence of knowledge among pupils of the catering schools complex and their place of residence on the way of nutrition and the state of nourishment]. Roczn PZH 1991;42:325.

28. Komosińska K, Woynarowska B, Mazur J. Zachowania żywieniowe związane z żywieniem u młodzieży szkolnej w latach 1990-1998 [in Polish] [Nutritional behaviours connected with nutrition among school youth in 1990-1998]. Żyw Człow Metab 2001;28(1):17.

29. Kozieł D, Naszydłowska E, Trawczyńska M, Czerwiak G. Zachowania zdrowotne młodzieży - kierunek działania dla edukacji zdrowotnej [in Polish] [Health behaviours of youth - direction of actions for health education]. Zdr Pub/ 2003;113(3/4):280-284.

30. Naszydłowska E, Kozieł D, Trawczyńska M. Ocena zachowań zdrowotnych młodzieży oraz ustalenie kierunków ich modyfikacji [in Polish] [An assessment of health behaviours of youth and determining the direction of the their modification]. Annales Universitatis Mariae Curie-Skłodowska. Sect. D, Medicina 2003;57(suppl 13)169:354-359.

31. Lewko J, Polityńska-Lewko B, Sierakowska M, Krajewska-Kułak E. Zachowania zdrowotne wśród studentów pielęgniarstwa [in Polish] [Health behaviours among students of nursing]. Annales Universitatis Mariae Curie-Skłodowska. Sect. D, Medicina 2005;60(suppl 16)283:260-264.

32. Gawęcki J, Hryniewiecki L, editors. Żywienie człowieka. Podstawy nauki o żywieniu [in Polish] [Human nutrition. Basics of science of nutrition]. Warszawa: Wydawnictwo Naukowe PWN; 2005.

33. Woynarowska B. Zachowania żywieniowe u młodzieży w wieku 11-15 lat w Polsce i ich niektóre skutki zdrowotne i społeczne [in Polish] [Nutritional behaviours of Polish youth aged 11-15 and some health and social effects]. Standardy Med 2004;187-94.

34. Jeżewska-Zychowicz M. Zachowania żywieniowe i ich uwarunkowania [in Polish] [Health behaviours and their determinants]. Warszawa: Wydawnictwo SGGW; 2007. 
35. Ilow R, Regulska-Ilow B, Sarzała-Kruk D, Biernat J. Ocena zwyczajów żywieniowych licealistów Oleśnicy [in Polish] [An assessment of nutritional behaviours of secondary school pupils of Oleśnica]. Bromatol Chem Toksykol 2008;3:705-710.

36. Gajda R, Jeżewska-Zychowicz M. Zachowania żywieniowe młodzieży mieszkającej w województwie świętokrzyskim - wybrane aspekty [in Polish] [Nutritional behaviours of youth living in the Świętokrzyskie Province - selected aspects]. Probl Hig Epidemiol 2010;91(4):611-617.

37. Dubois L, Girard M, Potvin Kent M. Breakfast eating and overweight in a pre-school population: is there a link? Public Health Nutr 2006;9(4):436-42.

38. Vanelli M, lovane B, Bernardini A, et al. Breakfast habits of 1202 northern Italian children admitted to a summer sport school. Breakfast skipping is associated with overweight and obesity. Acta Biomedica 2005;76(2):79-85.

39. Suliga E. Zachowania zdrowotne związane z żywieniem wśród uczniów szkół średnich [in Polish] [Health behaviours connected with nutrition among secondary school youth]. Now Lek 2002;71(2/3):107-111.

40. Hamułka J, Gronowska-Senger A, Tomala G. Częstotliwość i wartość energetyczna śniadań spożywanych przez młodzież szkól ponadpodstawowych [in Polish] [The frequency and energetic value of breakfasts eaten by secondary school youth]. Roczn PZH 2002;53(1):81-89.

41. Piotrowska E, Żechałko-Czjkowska A, Biernat J, Mikołajczak J. Ocena wybranych cech stylu życia kształtujących stan zdrowia 16-18 letnich dziewcząt. Cz. I. Stosowanie różnych diet, aktywność fizyczna, palenie papierosów [in Polish] [An assessment of selected features of lifestyle shaping the health status of 16-18-year-old girls. Part I. Applying various diets, physical activity, smoking cigarettes]. Roczn PZH 2009;60(1):51-58. 